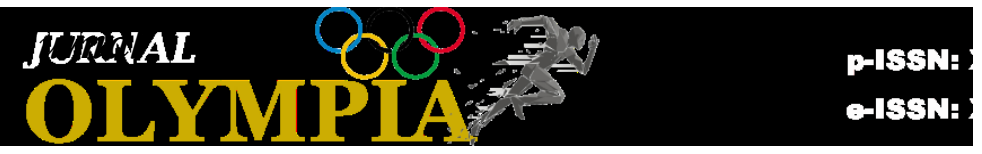

http://journal.binadarma.ac.id/index.php/olympia

\title{
Survei Kadar Hemoglobin Setelah Bermain Futsal di Dalam Ruangan (Indoor) dan di Luar Ruangan (Outdoor) pada Tim Futsal SMAN 1 Watansoppeng
}

\section{Arrahman $^{1}$}

Universitas Muhammadiyah Cirebon, Indonesia ${ }^{1}$

\begin{tabular}{l}
\hline Info Artikel \\
\hline Sejarah Artikel: \\
Diterima Februari 2020 \\
Disetujui Maret 2020 \\
Dipublikasikan \\
Mei 2020 \\
\hline Keywords: Hemoglobin \\
levels, indoor futsal, \\
outdoor futsal \\
\hline
\end{tabular}

\begin{abstract}
Abstrak
Tujuan penelitian ini 1) untuk mengetahui kadar hemoglobin setelah bermain futsal di dalam ruangan (indoor) pada Tim Futsal SMAN 1 Watansoppeng, 2) untuk mengetahui kadar hemoglobin setelah bermain futsal di luar ruangan (outdoor) pada Tim Futsal SMAN 1 Watansoppeng. Metode penelitian yang digunakan penelitian kuantitatif dengan pendekatan survey. Sampel yang digunakan 10 orang dari tim futsal SMAN 1 Watansoppeng. Tehnik pengumpulan data menggunakan tes haemometre atau automatic blood cell counter. Analisis data menggunakan deskriptif kuantitatif. Hasil penelitian menunjukan 1) terdapat 3 orang (60\%) yang kadar hemoglobinnya normal pada tim futsal SMAN 1 Watansoppeng setelah bermain futsal di dalam ruangan (indoor), 2) terdapat 2 orang (40\%) yang kadar hemoglobinnya normal pada tim futsal SMAN 1 Watansoppeng setelah bermain futsal diluar ruangan (outdoor).
\end{abstract}

\section{Abstract}

The purpose of this study 1) to determine hemoglobin levels after playing futsal indoors on the SMAN 1 Watansoppeng Futsal Team, 2) to determine hemoglobin levels after playing futsal outdoors on the Futsal Team at SMAN 1 Watansoppeng. The research method used is quantitative research with a survey approach. The sample used was 10 people from the futsal team of SMAN 1 Watansoppeng. Data collection techniques using haemometre tests or automatic blood cell counters. Data analysis using quantitative descriptive. The results showed 1) there were 3 people (60\%) whose hemoglobin levels were normal on the futsal team of SMAN 1 Watansoppeng after playing futsal indoors, 2) there were 2 people (40\%) whose hemoglobin levels were normal on the SMAN 1 futsal team Watansoppeng after playing futsal outdoors. 


\section{PENDAHULUAN}

Olahraga telah mendapat tempat dalam duniakesehatan sebagai salah satu faktor penting dalam usaha pencegahan penyakit. Olahraga terbukti pula dapat meningkatkan derajat kesehatan dan tingkat kesegaran jasmani seseorang (Samihardja, 1995). Kesegaran jasmani yang lebih tinggi dapat meningkatkan penampilan para olahragawan dan mengurangi kemungkinan terjadinya cedera. Masalah kesehatan sangat erat kaitannya dengan kehidupan masyarakat sekarang, salah satunya akibat penerapan pola hidup yang kurang baik seperti buruknya pola makan, aktivitas, kebersihan diri dan lingkungan. Timbulnya masalah kesehatan akibat pola hidup yang kurang baik dapat memicu timbulnya penyakit seperti jantung, hipertensi, diabetes mellitus.

Kesehatan seseorang dapat di tentukan dari tingkat kebugarannya, karena orang yang bugar memiliki kecendrungan untuk menjadi insan yang sehat. Seseorang dikatakan sehat dilihat tidak hanya dari fisiknya saja, tetapi dilihat juga dari beberapa faktor lainnya seperti jiwa dan sosial (Hidayat, 2019). Sesuai dengan pengertian menurut World Healt Organization (WHO). Sehat adalah suatu keadaan sejahtera sempurna dari fisik, mental dan sosial yang tidak hanya terbatas dari bebas dari penyakit atau kelemahan saja. Kebugaran merupakan bagian penting dari kesehatan. Komponen yang mendukung dalam meningkatkan kebugaran adalah berolahraga. Olahraga merupakan salah satu aktivitas fisik yang dapat meningkatkan kulaitas kesehatan individual dan mencegah berbagai penyakit (Sampoerno, 2008). Kurangnya aktifitas fisik merupakan faktor risiko tertinggi ke-empat terhadap angka mortalitas global. Olahraga juga berperan penting dalam kegiatan suatu individu dalam menjaga kesehatannya. Seseorang bisa dikatakan sehat apabila segala sesuatu dalam tubuh berada dalam keadaan normal termasuk kadar hemoglobin (Handoko: 2009).

Salah satu olahraga yang cukup populer dikalangan masyarakat khususnya di daerah perkotaan yang cukup diminati mulai dari anak-anak usia sekolah dasar hingga lanjut usia yaitu cabang olahraga futsal. Permainan futsal juga banyak dimainkan dalam lingkungan sekolah maupun masyarakat sehingga dapat menunjang minat seseorang atau siswa untuk memperdalam olahraga futsal seperti halnya di SMAN 1 Watansoppeng Kabupaten Soppeng. Pada tim futsal SMAN 1 Watansoppeng Kabupaten Soppeng mempunyai dua opsi sebagai tempat berlatih atau bertanding yaitu bermain futsal didalam ruangan (indoor) dan diluar ruangan (outdoor). Dengan semakin majunya era teknologi dan informasi, manusia dituntut semakin kritis untuk mencari tempat olahraga dimana fasilitas yang disediakan tidak hanya terpusat untuk olahraga tetapi juga memberikan suasana nyaman yang bisa membuat orang betah berada ditempat tersebut. Salah satu fasilitas umum masyarakat yang mewadahi aktivitas olahraga adalah sport centre yang memegang peranan dalam 
perkembangan olahraga. Selain dengan pengadaan fasilitas untuk berolahraga baik berupa ruang publik (terbuka)/lapangan (outdoor) maupun yang bersifat gedung olahraga/sport hall (indoor) untuk meningkatkan budaya dan prestasi olahraga maka dilakukan juga program pelatihan, pembinaan yang terarah dan terpadu serta berkelanjutan.

Kebutuhan masyarakat di Kab. Soppeng terhadap fasilitas olahraga tidak kalah dengan kota-kota besar lainnya, mulai dari anak-anak, remaja maupun dewasa. Mereka cenderung mencari suatu tempat olahraga outdoor dimana mereka bisa melakukan olahraga pada pagi hingga sore hari. Disamping itu juga, tersedianya fasilitas olahraga indoor sehingga untuk mereka yang tidak sempat melakukan olahraga outdoor bisa menikmati fasilitas olahraga indoor. Olahraga Indoor yaitu dimana cabang olahraga yang dimainkan dapat dilakukan di dalam ruangan saja dan tidak memerlukan tempat yang terbuka. Olahraga diluar ruangan (Outdoor) yaitu cabang olahraga yang dimainkan hanya dapat dilakukan diluar ruangan dan membutuhkan tempat yang terbuka. Olahraga ini biasanya tidak dibatasi oleh suhu, kecepatan pergerakan angin.

Namun demikian berolahraga didalam ruangan (indoor) dan diluar ruangan (outdoor) memiliki beberapa perbedaan. Masing-masing memiliki dampak positif dan dampak negatif. Pada olahraga diluar ruangan (outdoor) selain memperoleh vitamin $\mathrm{D}$ yang didapat dari terpaan sinar matahari olaharaga diluar ruangan (outdoor) juga memberi banyak pasokan oksigen $\mathrm{O} 2$ yang sangat diperlukan jaringan tubuh agar dapat menjalankan fungsinya dengan sempurna.

Akan tetapi olaharaga diluar ruangan (outdoor) tidak bisa terhindar ketika hujan turun, berbeda halnya dengan berolahraga didalam ruangan (indoor) tetap bisa berolahraga walaupun hujan. Selain dampak positif berolahraga dalam ruangan (Indoor), juga ada dampak negatif atau efek negatif terhadap tubuh. Beberapa faktor yang mempengaruhi aktifitas olahraga salah satunya faktor lingkungan dalam hal ini Oksigen (O2). Berolahraga dalam ruangan secara otomatis akan kekurangan oksigen (O2) sehingga berpengaruh sistem kerja otot dan sistem kardiovascular lainnya "oksigen merupakan kebutuhan hidup yang paling pokok, karena menit demi menit dalam kehidupan kita tidak mungkin lepas dari oksigen (O2)".

Penurunan tegangan dari $\mathrm{O} 2$ mempunyai suatu pengaruh yang langsung pada kejenuhan hemoglobin dan sebagai konsekwensi dari pengangkutan oksigen. Penelitian sebelumnya oleh Roberts, dkk (1999) menyimpulkan bahwa latihan yang maksimal yang baik dari suatu individu dapat menginduksi hipoksemia dan meningkatkan tingkat eritropoietin. Hemoglobin merupakan protein globuler yang dibentuk dari 4 sub unit dan setiap sub unit mengandung hame hameoglobin yaitu suatu protein yang membawa oksigen dan yang memberi warna merah pada sel darah merah olahraga secara umum mempengaruhi fungsi 
sistem pernafasan, sirkulasi, neuromuscular dan endokrin.

Pada sistem sirkulasi salah satu perubahan yang terjadi adalah perubahan parameter hematologis, perubahan ini meliputi peningkatan leukosit dan eritrosit. Peningkatan komponen hematologis ini (eritrosit) berkaitan erat dengan peningkatan hemoglobin darah, kadar hemoglobin darah meningkat sebagai mekanisme kompensasi terhadap keadaan kekurangan oksigen akibat aktivitas fisik yang meningkat. Karena pada saat seseorang melakukan aktivitas fisik atau berolahraga terjadi peningkatan aktivitas metabolik yang tinggi, proses metabolik dalam tubuh memproduksi asam seperti (ion, hidrogen dan asam laktat) semakin banyak asam tersebut di produksi dalam tubuh mengakibatkan terjadinya penurunan $\mathrm{PH}$. PH yang rendah akan mengurangi daya tarik antara oksigen dan hemoglobin. Hal ini menyebabkan hemoglobin melepaskan lebih banyak oksigen sehingga meningkatkan pengiriman oksigen ke otot.

Tujuan penelitian ini untuk: 1) mengetahui kadar hemoglobin setelah bermain futsal di dalam ruangan (indoor) pada Tim Futsal SMAN 1 Watansoppeng, 2) mengetahui kadar hemoglobin setelah bermain futsal di luar ruangan (outdoor) pada Tim Futsal SMAN 1 Watansoppeng. Membuat gambaran (profiles) Tim Futsal SMAN 1 Watansoppeng harus sesuai. Hal lain juga diungkapkan Bangkit Seandi Taroreh (2012:122-131) melakukan penilaian terhadap kemampuan dan kemajuan kompetensi harus secara utuh.

\section{METODOLOGI PENELITIAN}

Metode penelitian yang digunakan penelitian kuantitatif dengan pendekatan survey (Sugiyono, 2018). Penelitian ini memiliki dua variabel, yakni kadar hemoglobin dan tim futsal SMAN 1 Watansoppeng, baik bermain futsal didalam ruangan (indoor) maupun bermain futsal diluar ruangan (outdoor). Futsal merupakan kegiatan ekstrakulikuler yang dikembangkan sesuai minat dan bakat siswa. Hal ini juga diungkapkan Bangkit Seandi Taroreh (2017:41-47) bahwa di luar negeri sekolahsekolah sudah mengembangan berbagai kegiatan aktifitas fisik.

Sampel yang digunakan adalah pemain futsal perincian 10 orang dari tim futsal SMAN 1 Watansoppeng yang dibagi menjadi dua tim untuk dipertandingkan dengan tim futsal yang lain, baik didalam ruangan (indoor) maupun dipertandingkan diluar ruangan (outdoor).

Data dikumpulkan sesuai dengan variabel yang terlibat, yakni data kadar hemoglobin setelah bermain futsal pada tim futsal SMAN 1 Watansoppeng, baik di dalam ruangan (indoor) maupun diluar ruangan (outdoor). Pengumpulan data dilakukan dengan cara pengambilan sampel darah menggunakan alat yang dinamakan haemometre atau automatic blood cell counter (alat pengukur sel darah otomatis) dengan nama alat Easy Touch GCHB yang telah di registrasi oleh Departemen Kesehatan Republik Indonesia AKL No: 20101902214. 
Analisis data melalui pendekatan deskriptif kuantitatif dengan rumus:

$$
\mathrm{P}=\frac{F}{N} \times 100
$$

\section{HASIL DAN PEMBAHASAN}

Berdasarkan penelitian diperoleh hasil statistik deskriptif yaitu:

Tabel 1. Statistik Deskriptif

\begin{tabular}{lcccccccc}
\hline \multicolumn{8}{c}{ Statistik Deskriptif } \\
& $\mathrm{N}$ & Range & Min & Max & Sum & Mean & SD & Variance \\
& & & & & & & & \\
\hline Indoor & 5 & 2.50 & 13.70 & 16.20 & 74.00 & 14.80 & 1.191 & 1.420 \\
& & & & & & & & \\
\hline Outdoor & 5 & 2.60 & 12.20 & 14.80 & 66.50 & 13.30 & 1.157 & 1.340 \\
& & & & & & & & \\
\hline
\end{tabular}

\section{Sumber : Data Peneliti}

1) Tabel 1 menunjukkan nilai rata-rata pada kadar hemoglobin pemain futsal didalam ruangan (indoor) yaitu: 14.80 dengan nilai standar deviasi yaitu: 1.191. Penggunaan dari standar deviasi yaitu untuk melihat sebaran rata-rata sampel. Standar deviasi ini jauh dari sebaran rata-rata, hal ini menunjukkan nilai minimumnya yaitu: 13.70 dan nilai maximumnya 16.20. Berdasarkan kadar normal hemoglobin 14-18 gr/dl dapat disimpulkan bahwa nilai rata-rata pemain futsal di dalam ruangan (indoor) berada dalam kategori normal.

2) Tabel 1 menunjukkan nilai rata-rata pada kadar hemoglobin pemain futsal diluar ruangan (outdoor) yaitu: 13.30 dengan nilai standar deviasi yang tinggi yaitu: 1.157. Standar deviasi ini jauh dari sebaran rata-rata hal ini menunjukkan nilai minimumnya 12.20 dan nilai maximumnya 14.80 . Berdasarkan kadar normal hemoglobin 14-18 gr/dl dapat disimpulkan bahwa nilai rata-rata pemain futsal diluar ruangan (outdoor) berada dalam kategori di bawah normal.

3) Presentase data kadar hemoglobin tim futsal SMAN 1 Watansoppeng setelah bermain futsal didalam ruangan (indoor) sebagai berikut:

Tabel 2. Presentase data kadar hemoglobin setelah bermain futsal didalam ruangan (indoor)

\begin{tabular}{|c|c|c|c|}
\hline $\mathbf{H b}$ & $\begin{array}{l}\text { Bermain Futsal } \\
\text { didalam ruangan } \\
\text { (indoor) }\end{array}$ & f & $\%$ \\
\hline rmal & $14 \mathrm{~g} / \mathrm{dl}-18 \mathrm{~g} / \mathrm{dl}$ & 3 orang & $60 \%$ \\
\hline idak & $<14 \mathrm{~g} / \mathrm{dl}$ & 2 orang & $40 \%$ \\
\hline
\end{tabular}

Normal

Sumber : Data Peneliti

4) Presentase data kadar hemoglobin tim futsal SMAN 1 Watansoppeng setelah bermain futsal diluar ruangan (outdoor) sebagai berikut:

Tabel 3. Presentase data kadar hemoglobin setelah bermain futsal diluar ruangan (outdoor).

\begin{tabular}{cccc}
\hline Hb & $\begin{array}{c}\text { Bermain Futsal } \\
\text { diluar ruangan } \\
\text { (outdoor) }\end{array}$ & f & \% \\
\hline Normal & $14 \mathrm{~g} / \mathrm{dl}-18 \mathrm{~g} / \mathrm{dl}$ & 2 orang & $40 \%$ \\
\hline Tidak & $<14 \mathrm{~g} / \mathrm{dl}$ & 3 orang & $60 \%$ \\
Normal & & & \\
\hline \multicolumn{4}{c}{ Sumber : Data Peneliti }
\end{tabular}

Kadar hemoglobin di bawah normal disebut anemia, anemia merupakan keadaan 
menurunnya kadar hemoglobin, hemtokrit dan jumlah sel darah merah di bawah nilai normal yang dipatok untuk perorangan. Anemia sebagai keadaan dimana level hemoglobin rendah karena kondisi patologis. Anemia biasa disebabkan karena kekurangan zat besi dalam tubuh. Aktivitas olahraga yang dapat berhubungan dengan hemoglobin adalah aktivitas olahraga yang rutin. Dalam penelitian ini di temukan tidak ada hubungan aktivitas olahraga futsal yang berdurasi 2 × 20 Menit, baik bermain futsal dalam ruangan (indoor) maupun bermain futsal diluar ruangan (outdoor) terhadap hemoglobin. Hal ini sudah pernah di simpulkan oleh penelitian sebelumnya yang berjudul "Hubungan aktifitas fisik terhadap kadar hemoglobin pada mahasiswa anggota UKM pendekar Universitas Andalas. Karena peningkatan kadar hemoglobin hanya terjadi pada aktivitas olahraga yang rutin. Penelitian sebelumnya oleh (Ewangga, 2015) menyimpulkan bahwa kadar hemoglobin dapat meningkat dengan olahraga yang dilakukan secara rutin ini disebabkan adaptasi fisiologis tubuh ketika terjadi peningkatan kebutuhan oksigen. Namun untuk mengetahui kadar hemoglobin normal seseorang itu penting karena seseorang dikatakan sehat apabila segala sesuatu didalam tubuh dalam keadaan normal termasuk kadar hemoglobin.

Peningkatan prestasi futsal banyak dipengaruhi variabel lain selain kadar hemoglobin misalnya faktor keterampilan, taktik permainan, mental sehingga pelatih perlu memperhatikan variabel lain secara menyeluruh. Hal ini juga perlu diperhatikan untuk meningkatkan teknik keterampilan harus memperhatikan komponen biomotorik (M. Haris Satria dan Bangkit Seandi Taroreh, 2019:44-50).

\section{SIMPULAN}

Simpulan penelitian ini bahwa:

1) Terdapat 3 orang $(60 \%)$ yang kadar hemoglobinnya normal pada tim futsal SMAN 1 Watansoppeng setelah bermain futsal di dalam ruangan (indoor).

2) Terdapat 2 orang (40\%) yang kadar hemoglobinnya normal pada tim futsal SMAN 1 Watansoppeng setelah bermain futsal diluar ruangan (outdoor).

Untuk penelitian selanjutnya disarankan menggunakan sampel yang lebih banyak dan variabel yang lebih kompleks misalkan usia, gizi, asam laktat dll.

\section{DAFTAR PUSTAKA}

Bangkit Seandi Taroreh. (2012). Model Performance Assessment of Learning Outcomes Of Volley Ball in Elementary School. Journal of Physical Education and Sports, 1(2), 122-131.

Bangkit Seandi Taroreh. (2017). Development Model Approach Through Exercise Kinesthetic Game Circuit for Children Ages 4-6 Years. Journal of Indonesian Physical Education and Sport, 3(1), 4147.

Ewangga, B. Ieva, B. Akbar, A \& Nilapsari, R. (2014). Perbedaan Kadar Hemoglobin yang Berolahraga Futsal dan Tidak Berolahraga: Bandung. 
Handoko. (2009). Manajemen olahraga. Edisi ke-2. Yogyakarta: BPFE.

Hidayat, A. (2019). Effect Of Agility Ladder Exercises On Agility Of Participants Extracurricular Futsal At Bina Darma University. Journal of Physics: Conference Series, 1402(5). https://doi.org/10.1088/17426596/1402/5/055003

Sampoerno, D. (2008). Membangun Bangsa yang Sehat Produktif. Kesmas: National Public Health Journal. https://doi.org/10.21109/kesmas.v3i1.239

Sugiyono. (2018). Metode Penelitian Kuantitatif,Kualitatif dan R\&D. In ke-26.

M. Haris Satria., Bangkit Seandi Taroreh. (2019). Hubungan Kelincahan, Kecepatan, Dan Keseimbangan Dengan Keterampilan Menggiring Bola Pemain Sepakbola Universitas Bina Darma. Riyadhoh: Jurnal Pendidikan Olahraga,2 (1), 44-50.

Robert D, Smith D. J. (1999). Erythropoietin Concentration and Arterial Haemoglobin Saturation with Supramaximal Exercise. Journal of Sports Sciences, 17(6): 485493.

Samihardja, J. (1995). Peranan Ilmu-Ilmu Kedokteran Dalam Peningkatan Prestasi Olahraga Dalam Buku: Simposium dan Diskusi Panel Peningkatan Prestasi Olahraga. Semarang.

World Health Organization. (2010) Global Recommendations on Physical Activity for Health. Geneva, Switzerland: WHO Press. 